never have been able to accomplish what she has without the previous training which she had in district nursing work.

Mrss Rocrss.-I think that is very important, Miss Carr. I think I myself would not have gotten along as well if I had not had the training in the Nurwes' Settlement. In selecting our nurses we make that a very strong point. If a nurse has not had training in that sort of work or has had no training outaide of the hospital, we feel that we had better select one who has had, although that does not debar her from being taken on the staff.

MIss WaId.-We will proceed with our programme and hear a paper by Mrs: von Wagner, who has successfully proven the efficiency of the nurwe in one other phase of public work, and that is in the inspection of tenement houses.

\title{
THE NURSE AS TENEMENT-HOUSE INSPECTOR
}

Br JOHANNA VON WAGNER

Sanitary Inspector of Tenements, Yonkers, N. Y.

" Eight years ago I commenced the work of tenement-house inspection in Yonkers. The Civic League had been requested to look into the housing conditions by the Health Officer, who was unable to cope with the problem. Following the example of many cities of Great Britain, a woman inspector was chosen. The experiment having proved successful, the Board of Health was persuaded to adopt the office in the beginning of the year 1900 .

"It has been a great experience as well as a privilege to work in connection with one of the most important offices in the city's government. To have the right to enter all premises at all times, to come in contact with all phases of human life and misery, is in itself a liberal education. The fact of my being a nurse made the work more effective and beneficial.

"Our most precious possession is health, and if a nation's wealth is its health, then all efforts towards better public health should be increased and encouraged. Public health can be improved only by better sanitation and hygiene, which comes under the head of preventive medicine, the knowledge of which is so wofully lacking in most of our homes. It is a field that rightly belongs to doctors and nurses, and may the near future see more teachers in our professions than simply healers.

"The greatest good derived from tenement inspection is the knowledge of housing conditions and bringing them before the public, and once the facts are published the remedy for better conditions must be found. It is astonishing how little one-third of the people know and care to know about their neighbors who are allowed to live by the grace of landlords in so-called tenements.

"A tenement house is one of three families or more, and even in 
Yonkers we have houses with twenty to thirty families-six families on one floor, two in the front, two in the middle, and two in the rear; front and rear have light rooms, middle rooms have air-shafts. Imagine people condemned to live without sunshine and very often without air! Yards are more and more disappearing and people take their recreation on the streets, which life is especially harmful to children.

"In large tenement houses ashes and garbage very often are kept in cellars or under areas for lack of space, which causes a great nuisance, as in very few cities refuse is removed every day-in Yonkers only once a week, in winter perhaps once in two weeks. The only windows that might be opened very often have to be kept closed because of the offensive odors arising from decomposing animal and vegetable matter.

"Another disadvantage in tenement houses is the lack of closets and store-rooms; a great many tenants have only a dish closet, so clothing and food are suspended on lines in kitchen and bedrooms. Fireescapes are used for cold storage in winter and, of necessity, hot storage in summer. Soiled clothes are usually kept under the bed until washday, the garbage-pail and wet rags under the sink until such time as it is convenient to make a journey down to the cellar or yard, and if toilets are not on the same floor a slop-pail is suspended from the window, much to the annoyance of the tenant on the floor below, or is kept in the hall or bedroom and becomes a positive nuisance when kept for days.

"Yard and cellar toilets are a hardship for any tenant, besides being in nearly every instance a nuisance. Women with large families of small children have to keep a slop-pail somewhere, as it would be impossible to climb three or more stairs whenever needed. Toilets in yards are apt to become out of order, especially in winter, when the water freezes and the usual condition of overflowing toilets occurs and tenants throw slops on the ground. Toilets placed in cellars are perhaps even more of a nuisance-first of all because of the darkness, and, second, of the bad odors that permeate the house, as such places are apt to be very filthy. It is not unusual to stumble over a drunken man who has gone down to the cellar to sleep off his debauch; this happens when the first floor is a saloon. 'Lady, don't go down there, there is a drunken bum!' Women tell me that children refuse to take necessary remedies because they do not want to go down to the cellar. It was in a family that had always lived where toilet accommodations were in the cellar that after moving to better quarters the little girl said to me, ' Oh Miss von Wagner, we have the cellar on the floor with us now,' the toilet being in the hall in the new flat. Those that have done district nursing and had occasion to spend day and night in such places can readily realize the hardships of such conditions. .

"Sinks are very often placed in halls, and three or more families 
use one sink, which on washdays, early mornings, and evenings when the men and women return from work presents an interesting sight-a line of people waiting their turn to wash off. Among the foreign population washbasins are unknown and ablutions are performed under the faucet. Once a week, usually Saturday afternoon or erening, a tab is filled with water and placed in the kitchen, and should one enter at the right time one can see half a dozen men bare to the waist standing around the tub bathing at the same time; in the same way the family shares the tub later on in the evening.

"Just think how hard it is to keep clean under such conditions. No wonder a woman said to me a few days ago that if the landlords would only put a bath in the basement for the use of the tenants, it certainly would be a blessing in these densely populated districts and prevent a great deal of disease.

"Overcrowding is one of the inevitable and worst features of our present day tenement-house life. Immigrants certainly come here with the idea of bettering their conditions and earning more money. They do not earn sufficient to live-decently and save, which is their greatest aim, so in, order to sare all rooms are sublet except the kitchen, which serres the family as living- and sleeping-room; sometimes the whole family occupy one bed, especially if the children are small. The boarders are packed in according to the size of the room-two, four, six, or eight-8ometimes the night workers going right in and occupying the beds vacated by the day workers. The characteristic bedroom smell cannot be gotten rid of even with good ventilation. Fancy the condition if bedrooms are not ventilated!

"The family that is striving hard to save money is the one that suffers most. The woman receives from each boarder two and one-half dollars for sleeping and washing per month; the men and women feed themselves, which is simple enough, as each one has his own loaf of bread and coffee-kettle. The woman cooks a large pot of soup and dough similar to macaroni and the boarders can have a dishful for a few cents. There is great competition among these women for keeping boarders, and that is the reason board is so cheap.

"The effect on family life is demoralizing, besides being deadly. The little children die for want of air more than from any other cause, especially those under one year. If they survive the first year, they are very apt to succumb to digestive disturbances during the second or third year, because nothing is too good for the baby-sauerkraut, sausage, meats of all kinds, cucumbers, tomatoes, and now and then a glass of beer or a little wine, even whiskey. Do we wonder at our high. deathrate among children under fire years of age? When I tried to stop a 
woman from pouring a glass of beer down the baby's throat she said, 'It is only for good luck.'

"The larger children live the life of the street, and where else could they be? The vices and temptations of such a life leave their mark upon the young, and reformatories and prisons are filled greatly from these congested centres. If not morally, the child has suffered physically, grows up a weakling, enters the factory, is a prey to tuberculosis, dies young, or else survives long enough to get married and before many years leaves a widow and usually sickly children. The girl does not fare much better; factory life is not conducive to good health or self-development; a great many. joung girls die of consumption; if they live and marry, they are unable to make homes; they know nothing about motherhood. The lack of that knowledge is paid for dearly in the waste of human life; almost without exception the first-born children die, and in most families many more follow. The unnecessary grief, expense, and ensuing poverty might have been saved. 'A birth and a death every year,' as is often said; 'undertakers' bills are more expensive than raising children.' In a great many instances the death of a child is taken in a very matter-of-fact way; if any sympathy is extended, one is rebuked with: 'My child is not any too good for the Lord; if He wants it, $\mathrm{He}$ can have it.' When one considers their income of nine or ten dollars a week it is not surprising. Another cause for this indifference may lie in the evil of child insurance, especially under five years of age; it is customary among the foreign population to insure all children, even the infants. The woman frequently goes out to work to help along, which necessitates the neglect of children and is apt to tell on their physical as well as moral development.

"The drink problem is a great one in all industrial cities. Some factories compelling such unwholesome and hard work, men feel obliged to get stimulants from the everywhere present saloon. The men can always get credit there when working, and on payday that bill is the first one to be settled. Never mind the butcher and grocer. Credit is much more easily obtained there, and if anybody is the loser it is the latter. A shiftless drinking woman is not only a curse to her own household, but a bad example to the neighbors; she will invite others to share a drop and household duties are neglected; proper meals not provided, and dirt and disease soon follow. I have known many nice young women to be utterly ruined by such examples. It is much harder to break up this habit in women than in men; once in a while a man will take the pledge and keep it, while a woman most always will suffer relapses. Visiting in such homes helps a great deal, befriending and advising and suggesting proper nourishment, keeping the woman well 
occupied and not forgetting to furnish a little pleasure in her life of drudgery; in winter taking her to some good entertainments and lectures, in summer giving the families outings-something to look forward to, something to add to her life, to make living worth while; making her acquainted with the beauties of nature, art, and music; giving her something else to think about besides where the next meal is coming from. It will make her gentler and certainly happier. One widow who had for thirty years desired to have a piano had at last been able to get one-thirty years of washing $!$ and then the piano came on the instalment plan; a grown-up daughter was to take lessons. As I entered I heard the queerest noise-someone playing softly and singing without the least idea of keys or tune; I looked in and saw my friend on the piano-chair, the greatest joy transforming her face-a pathetic sight. All these years had she waited, and now her wish was realized !

"When a woman tells you that for fourteen years she has not been away from home, has seen nothing, heard nothing new or helpful-has born ten children, lost six, has walked the floor nights because of worry, grief, or sickness-you feel that someone is to blame for such conditions. This is the case of many.

" "What did Yonkers do before you came?" the people often say. They know that I have come as a friend, and even the impossible is requested-not only to heal the sick, but care for the well, give them work or better positions, help the children to get a better education, to save them from factories, help them to learn a trade, go to business college, find decent houses for them to live in, place children in institutions, be a guardian until orphans are of age, spend my Sunday with the family -it keeps one so utterly busy that self is forgotten; so many people's burdens come into one's life that our own are never thought of. One only wishes that one could do more, help moro-and also wishes for more trained workers, especially nurses. 'What shall I do for the baby?' is the daily question. The many sore eyes, ears, the different deformities; tuberculosis; the prevention, spread, and isolation of contagious diseases-all prevention of these diseases would tend to lessen poverty, sorrow, and increase happiness, all of which comes under our province.

"Christ said, 'Go ye and preach the Gospel.' So must we go and give our knowledge and experience to the largest numbers and teach cleanliness and health to those that have a right to know and a duty to obey. Of what use is sanitary legislation if its laws are neither known nor enforced?

"The children seem to have the right idea of our work. 'Here comes the city,' they say at my approach. 'Lady, we will show you 
where the dirty floors are,' tells the tale. One girl, seeming very much interested, followed me from cellar to roof, and when I was ready to go exclaimed, 'Lady, is the Board of Health your husband?' A Polish woman came to the same conclusion. Entering the office where I happened to be alone, she asked, 'Where is the Mr. Board of Health?' I said he had gone out. Then she asked, "Are you the Mrs. Board of Health?' and stated her troubles. With the Italian children I am the policeman of the houses; with the English-speaking children I am the sanitary lady; to some I represent the law, to others cleanliness. It is by no means an easy work, even if the most interesting that falls to any worker. One deals with human life in all its aspects-certainly not appreciated by many landlords because of the expenditures in improving property, neither by the shiftless and dirty tenant, but always much appreciated by the much neglected children.

"But nothing should discourage us; we are the servants of the people and must consider their interests first and foremost and help them to their rights. The right to work they all have- the right to live decently society would deny them. The saloon for the man, the street for the child, the kitchen for the woman. Let us help to change this; let us work for airy, light, clean homes; parks, playgrounds, and baths for those who have been deprived of them, and so work out God's law- Love thy neighbor as thyself.'

"The great pity is that we do not know our neighbors in the city. The Italian, Slav, and Armenian live their own lives, bring their own customs, and cannot readily adapt themselves to new laws and civilized ways, and yet they wish to learn and better their conditions. The Hebrews and Italians are quicker to improve; the Slav is slow and stubborn-it takes more patience and time to overcome deep-rooted superstition and prejudices, but even there I see improvement, and the first thing often said to me now is, 'I keep men no more; live all alone.'

"The people need a helping hand. The American citizen must become acquainted with his foreign brother and give personal service to prevent colonizing large bodies of foreign born. Our mission is right here in our own cities. Settlements have been of the greatest blessing, and it is in connection with them that the greatest good can be accomplished. To live among the people is the best way of knowing and influencing their home life. Personal service is needed even if we do break down-the individual often must be lost for the cause of all. The nurses entering this field will feel, I am sure, as $I$ do, that it is a privilege as well as a help to self-development to do work in which one constantly has to appeal to the best in human nature.

"In the city's housekeeping woman has her place, and the nurse 
especially is well fitted to fill it. Woman is more practical and economical by nature than man, and it is with women we deal in the homes. It is our right and duty to share in the work.

"When contagious disease breaks out, besides inspecting the premises the condition of the sewer is ascertained and the Department of Public Works notified. The present outbreak of meningitis I have often thought had some connection with unsanitary conditions in house or street; if sewers could be regularly flushed, I think all filth diseases could be lessened.

"Results from our work we should not look for, but leave it to God; no effort is ever lost. We sow the seed, and in the most unexpected way it will grow and multiply. Better homes, better citizens, more workers, less disease and poverty, more public-spirited citizens, more funds for relief, more public sentiment, better public government.

"The last result this year has been the organizing of a large body of men and women into the Sanitary League with the object of improving public health, at present devoting their energies to the prevention and spread of tuberculosis and isolation of patients in some hospital near Yonkers.

"I hope to have shown the need of nurses as sanitary inspectors sufficiently for many to prepare for and enter this field. Every city has a housing problem and therefore needs us.

"Let us go and preach the gospel of cleanliness. As Dr. Richardson said: "Cleanliness covers the whole field of sanitary labor; it is the beginning and end?"

Mrss WALD.-I am sure that all agree that Mrs. von Wagner's paper is a sermon, and we are all ready to subscribe to her text. The paper is open for discussion. If there is anyone here who can contribute anything further to the subject of the inspection of tenements, she will be most wlecome to take part; if there is anyone who has had experience or who can speak for the community we would like to hear her; or perhaps someone would like to ask questions of Mrs. von Wagner.

Mrss NurriNa.-I should like to ask if she has much difficulty with the landlords, whether it is the question of landlords or just where the special diffculty lies.

Mrs. voN WAGrER.-I think the greatest trouble lies with the landlord. He goes to the Common Councilman and to the Mayor; the landlords are the worst people to deal with; where I can get hold of a landlord I talk to him and tell him that I am working in his own interest, I am educating his tenant to be clean and take care of his property, and what I want him to do is to keep his house in good condition; it is much better for any landlord to repair his property and keep it as nicely as possible, because he can get better rents and a better class of tenants; it is in the most ramshackle buildings that people do not pay 
the rent; after I have educated the landlord then I get better conditions. I am always glad to see the landlords, but they do not like me; they have formed a Landlords' Protective Association, and their one aim and object is to remove that woman inspector, hut $I$ think in order to help them and defend myself, if $I$ had the means, I would immediately become a property owner, no matter how small, and I would join them.

Miss Ward.-I should like to ask Mrs. von Wagner if Yonkers has not had a Tenement-House Commission or whether the Sanitary League has not looked into the matter of the housing of the people, or whether some such movement is afoot.

Mrs. von Wagner.-No, it was the Civic League that took up the house inspection and made this position possible at first. Then I collected statistics and hrought before the puhlic the condition of the houses; it was so had that the Civic Cluh decided to take up the matter of the changing of the huilding code and the sanitary code. The worst kind of a tenement was possihle in Yonkers; one man who has travelled a great deal said about one house which we have and call Castle Garden that there was nothing like it in Glasgow or Edinhurgh, and the tenements in those cities are supposed to be the worst in Europe. Then the Civic Cluh appointed a committee to change the huilding code and the Board of Health changed the sanitary code. The lat of May the new law went into effect, and now we shall have better conditions.

Mrss Ward.-Before closing this topic I should like to say that there are tenement-house inspectors in the department of New York City. I believe that the nurse is very acceptahle, and, all other conditions being equal, that she has had the preference in receiving this appointment. Mrs. von Wagner would probahly know how many there were. Certainly when the question of the tenementhouse inspector came up the public tried very hard to get nurses who might have had some training or some qualifeation for this work. Their training in the hospitals, their accuracy in detecting disease, in knowing the difference between clean and unclean conditions, seemed to make them more desirable. I believe that as an actual fact not many nurses have been found who considered themselves fitted for the work; perhaps that is one suhject that may be discussed a little later on as to the further preparation of the nurse for the social and civic service.

Miss NuTrina.-Will Mrs. von Wagner let us know if she gave herself any special preparation for her work in the tenements? Is it necessary to study hygiene and sanitation?

Mas. von WAaser.-I would have liked that very much. There was no place to go to eight years ago, and I was called upon so suddenly to become an inspector of tenements, that I had to do the best I could. I had some very good text-books on practical plumbing sent to me, and $I$ went to a sanitary expert in New York and had some talks with him, and that really was all the preparation I could have, because I had to begin my work right away; then I kept in touch with the latest puhlications, and that was all my education on sanitation. 1 think now that any nurse who desires to become a sanitary inspector can fit herself a great deal better. That is why I am anxious to have the nurses take it up. There are doctors in New York City who will give lectures and instructions, and then you can go to places where that work is estahlished and learn from the experience of the workers. In New York the women inspectors had to prepare themselves in such a way and pass a civil-service examination. Don't be 
afraid of the civil-gervice examination; all you have to look up is your arith. metic, and with your preliminary training you will pass very well; it is not wo werious problem, and even if you never become sanitary inspectors the study of sanitation will help you. May I just say that women inspectors in New York are doing Board of Health work; they inspect the house on the same lines, and are, under no consideration, to speak with or have any dealings with the tenant; they leave the people altogether out of their work; it is simply reporting nuisances and reporting the condition of the house. I would not do that. The members of the Board of Health have been very kind in Yonkers. I have done the work according to my own ideas and according to the needs of the people. I never thought I could do what they have let me do, but they have never disturbed me in any way.

Mrse Parums.-I would like to ask Mrs. von Wagner if the fault is with the women or with the department.

MRs. voN WAGrer.-The fault is not with the women; it is with the de. partment; the women are forbidden to speak to the tenants; they just attend to their work of looking over the condition of the house and reporting it. Fifteen other cities have taken up the work since Yonkers commenced it. We have written to most of the cities in the United States asking if they have annitary in pectors simply to arouse their interests, I think, and most of them anwered No. But flfteen other cities have taken up the work, and where there have been women phyaicians employed as inspectors I am sorry to say they have been a failure. I think that work belongs to nurses in preference to physicians; they are a little more practical and do not mind the hardships. A woman physician is not always willing to devote her time to that; the work is so hard and takes up so much time one has to simply give one's life to it. I know of eeveral in. stances where it has been a complete failure, having been undertaken by women physicians who had no intereat in it.

Mras WarD.-This seoms to lead logically to a message that was entrusted to me and which I must confess I had almost forgotten. In New York and Boston and Chicago schools of philanthropy have been established. The one in Boston is under the combined auspices of Simmons and Harvard Colleges; in New York the Charity Organization Society is in control of the school and two sessions are offered to the public, one summer course and one winter course. The secretary of the Charity Organization Society of New York and the recently appointed occupant of the new chair in Columbia College, that of social work, very strongly desires that those nurses who wish to supplement their training by preparation for social work may attend these lectures, and he will arrange the courses to suit such pupils, giving them just what they need along these special lines. If there are a sufflcient number of nurses to justify him in having a course specially arranged for them, he will be most glad to do so; even the course now arranged by the school is admirably adapted to those who wish to take up what for lack of a better name we must call the more special work of a nurse,-the visiting nurse, the school nurse, the charity workers, and the various flelds that have been discussed or alluded to in to-day's programme. Besides that, there is the course at Teachers College which is under the direction of the superintendents and which, in fact, has led to a wider conception of the social opportunities of the nurse. The Boston School, to those who are near, must offer a great many opportunities for special training. I give this meseage with a great deal of pleasure, for it seems to me that the horizon is widening, 
and widening in that not only the nurse herself desires to take such part in the efforts for social betterment and social welfare, but that also the community desires and sometimes almost clamors for her. It is not necessary to make any formal application, but I am sure that the secretary will be glad to send the prospectus to those wishing it. This course has from time to time been

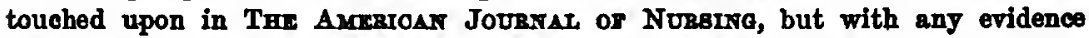
of a desire to hear in detail of it I doubt not that all the information will be given in the fullest manner. After all questions to Mra. von Wagner have ceased, I should like very much to ask the next speaker of the evening to present her paper. This again is on the lines that we have been following all day, that is, "The Relation of Nursing to Social and Philanthropic Work," Miss M. E. Bmith.

\section{THE RELATION OF NURSING TO SOCIAL AND PHILAN- THROPIC WORK}

BX MISS M. E. BMITH

Late Visiting Nurses' Association, Detroit, Mich.

"In taking up the subject which now challenges our consideration I shall not attempt to give any scientific definition or outline of social and philanthropic effort. It will be sufficient if we note some of the salient points connected with it, our purpose being to gain such a knowledge as shall clearly show the relation of nursing to this work.

"The work itself is as old as the human race, and its needs as varied. To successfully carry it on, the integrity of the family must be maintained, right relations must be established between rich and poor, and the responsibilities of the prosperous must be conscientiously assumed by them. It finds its best expression in charity strengthened by justice -charity without justice is as ineffective towards the betterment of mankind as a poultice would be applied to a wooden leg-would that it were as harmless! Charity without justice well merits the rebuke contained in the French epigram, 'Charity creates one-half of the misery she relieves, but cannot relieve one-half of the misery she creates,' and the sting is in the truth it expresses.

"It has been said that social questions are expressions of moral energy, and that the effectiveness of social and philanthropic effort lies in the scope of its sympathy, the dimensions of its givings, and its recognition of fellowship with lives hitherto ignored or rejected by the world. I will add that it also lies in the tendency of the current day towards associated effort for the carrying on of practical and specific benevolent work, and perhaps most of all in the love and hope, the courage and patience, the sympathy and wisdom, of those actively engaged in it, and who every day breathe into it new vigor and greater freedom.

"Thus far three things appear clear to us: 